\title{
In Vitro Chitosan Hydrogel Based Metronidazole Cytotoxicity Test on 3t3 Fibroblast Viability
}

\author{
Hilma Rasni ${ }^{1}$, Irma Ervina ${ }^{2 *}$, Syafruddin Ilyas ${ }^{3}$ \\ ${ }^{1}$ Periodontics Residency Program, Faculty of Dentistry, Universitas Sumatera Utara, Medan, \\ Indonesia \\ ${ }^{2}$ Department of Periodontics, Faculty of Dentistry, Universitas Sumatera Utara, Medan, Indonesia \\ ${ }^{3}$ Department of Biology, Faculty of Mathematic and Natural Science, Universitas Sumatera Utara, \\ Medan, Indonesia \\ *Email: irma_ervina@rocketmail.com
}

\begin{abstract}
The objective of this study is to determine the in vitro cytotoxicity effect of chitosan hydrogel-based metronidazole on fibroblast. Chitosan hydrogel-based metronidazole $(0.12 \%, 0.15 \%, 0.25 \%)$ and chitosan without metronidazole are made by dissolving lactic acid to reach a gel consistency, and then adding powdered metronidazole according to the concentration. 3T3 fibroblast cells were cultured in well mikroplate containing RPMI-1640 media inside an incubator. The cell viability tests were carried out using theMTT assay method and repeated five times. The colour degradation was read with a microplate reader. The mean viability of fibroblasts mixed with chitosan hydrogel-based metronidazole at concentration of $0.12 \%, 0.15 \%$, and $0.25 \%$, and chitosan without metronidazole were $96 \%, 93 \%$, $91 \%$ and $98.8 \%$ respectively. ANOVA statistical test results for the $0.12 \%$ concentration group, where $\mathrm{p}<0.05$ represents the cell's viability, significantly differs from the results for the $0.15 \%$ and $0.25 \%$ concentration groups. Chitosan hydrogel-based metronidazole shows non toxic effects on fibroblast cells.
\end{abstract}

Keywords: metronidazole, viability, cytotoxicity, fibroblast, chitosan.

\section{Introduction}

Periodontitis is a severe stage of periodontal disease caused by alveolar bone resorption and loss of attachment to the periodontal ligament, which acts as a tooth support [1]. The main purpose of periodontal therapy to completely remove the bacterial plaque and remove the periodontal pocket from the granulation tissue for optimal healing [2]. Generally, biofilm associated with anaerobic bacteria is the main etiology of periodontal disease [3]. Conventional periodontal disease treatment consists of mechanical debridement to remove subgingival microbiota and calculus by means of scaling and root smoothness. Some case require additional chemical treatment. Maintaining proper oral hygiene at home is important $[4,5]$. Chemical auxiliary treatment with antibiotic and antiseptic better for infection control and for controlling host tissue damage by using a host modulator [6]. Antibiotics may be given systemically and locally [7]. Introducing local antibiotics into the periodontal pocket is expected to achieve greater and stronger drug concentrations compared to systemic administration [8]. 
Metronidazole is a broad-spectrum antimicrobial that combats protozoal and anaerobic bacterial infections [9,10]. Today, metronidazole is one of the most widely used antimicrobials (with in an antibacterial compound) in the treatment of periodontal disease [11].

Hydrogels are cross-linked, three dimensional hydrophilic polymeric networks that swell but not dissolve when brought into contact with water [12]. Using chitosan hydrogel as a drug-delivery vehicle has been widely described in certain types of literature [13]. Chitosan has advantages over other polysaccharides, as it is biocompatible, biodegradable and non-toxic [14].

Research on the cytotoxicity effects of $3 \%$ chitosan hydrogel-based metronidazole $(0.12 \%, 0.15 \%$, and $0.25 \%)$ has never been done before. This research studies the cytotoxicity effects of chitosan hydrogel-based metronidazole, based on earlier research by Adha which studied the effectiveness of chitosan hydrogel-based metronidazole in inhibiting the growth of bacteria A. actinomycetemcomitans, $P$. gingivalis dan F. nucleatum invitro [15].

\section{Materials and Methods}

The chitosan, provided by the Chemistry Departement, Universitas Sumatera Utara, was processed from shrimp shells. In this research, the first process used $3 \%$ chitosan hydrogel-based metronidazole $(0.12 \% ; 0.15 \% ; 0.25 \%)$ and $3 \%$ chitosan hydrogel. Chitosan hydrogel-based metronidazole was made using methods from the formula described by Yellanki et al.[1]:

Table 1. Composition of the chitosan hydrogel-based metronidazole $0.12 \%, 0.15 \%$ and $0.25 \%$ and chitosan hydrogel without metronidazole

\begin{tabular}{|l|c|c|c|}
\hline \multicolumn{1}{|c|}{ Group } & $\begin{array}{c}\text { Metronidazole } \\
\text { (g) }\end{array}$ & Chitosan(g) & $\begin{array}{c}\text { Lactat Acid } \\
\text { (ml) }\end{array}$ \\
\hline $\begin{array}{l}\text { Chitosan hydrogel-based } \\
\text { metronidazole 0.12\% }\end{array}$ & 0.06 & 1.5 & 50 \\
\hline $\begin{array}{l}\text { Chitosan hydrogel-based } \\
\text { metronidazole 0.15\% }\end{array}$ & 0.75 & 1.5 & 50 \\
\hline $\begin{array}{l}\text { Chitosan hydrogel-based } \\
\text { metronidazole 0.25\% }\end{array}$ & 0.125 & 1.5 & 50 \\
\hline $3 \%$ Chitosan hydrogel & - & 1.5 & 50 \\
\hline
\end{tabular}

Chitosan hydrogel $(3 \% \mathrm{w} / \mathrm{w})$ was prepared by continous manual mixing of 1.5 grams of chitosan with an adequate amount of lactic acid (2\%). Metronidazole concentration of $0.12 \%, 0.15 \%$, and $0.25 \%$ were dissolved in the chitosan hydrogel.

3T3 fibroblast cell-lines were cultured in microplates containing Rosewell Park Memorial Institute 1640 (RPMI-1640) media to obtain a cell/well density of $1 \times 10^{4}$ and incubated for 24 hours. After the media were washed with PBS and refreshed, $25 \mu \mathrm{l}$ of each experimental hydrogels were then added to the microplate. This was followed by an incubation process at $37^{\circ} \mathrm{C}$.

After 24 hours, the solution in well was flicked off and $50 \mu 1$ of MTT assay was added to each well. Five well for each of the 4 the experimental groups. Each group's wells were repeated five times, yielding a total of 100 wells. 
$\%$ Cell viability $=\frac{(\text { Absorbance value of test compound }- \text { Absorbance value of blank })}{(\text { Absorbance value of test control }- \text { Absorbance value of blank })} \times 100$

The percentage of cell ihibition was calculated by substracting the percentage of cell viability from 100 . The Saphiro-Wilk normality test was conducted on the viability results, followed by the ANOVA test. The results were considered statistically significant when the $p$ value was $<0.05$

\section{Results}

The effects of cytotoxicity in chitosan hydrogel based metronidazole were assessed based on the absorbance values of $3 \mathrm{~T} 3$ fibroblast cells. The crystalline purple was calculated using a microplate reader 24 hours after the test material was applied to the 3T3 fibroblast cells. The test material takes on a certain colour and the absorbance value measures the polarization of light absorbed by a particular material at a certain wavelength.

Table 2 shows that the highest absorbance value on control cells containing fibroblast cells while the lowest on media control that contains RPMI media without 3 T3 fibroblast cells. Absorbance values are required to calculate the percentage of cell viability.

Table 3 shows chitosan hydrogel-based metronidazole $0.12 \%, 0.15 \%, 0.25 \%$ and $3 \%$ chitosan hidrogel seen that average percentage cell viability was $>90 \%$. It shows that gel chitosan hydrogel - based metronidazole is not toxic. Thus, chitosan hydrogel-based metronidazole $0.12 \%$, shows the highest viability compared with other concentrations.

Table 4 shows that the percentage value of viability of all groups of test materials is normally distributed, therefore, in this study used ANOVA method to analyze the differences between groups of test materials statistically.

Based on ANOVA test, the 3T3 fibroblast viability of each tested material shows that there is a statistical difference where the $p$ value is $<0.05$, the number of fibroblast cell are low and the concentration of metronidazole used is a higher.

Table 2. Absorbance result of each hydrogel group on $3 T 3$ fibroblast cells

\begin{tabular}{|l|c|c|}
\hline \multicolumn{1}{|c|}{ Groups } & Mean \pm SD & Min-Max \\
\hline Cell Control & $0.625 \pm 0.02$ & $0.591-0.645$ \\
\hline Blank Control & $0.080 \pm 0.005$ & $0.074-0.087$ \\
\hline $\begin{array}{l}\text { Chitosan hydrogel-based metroni- } \\
\text { dazole 0.25\% }\end{array}$ & $0.577 \pm 0.02$ & $0.523-0.587$ \\
\hline $\begin{array}{l}\text { Chitosan hydrogel-based metroni- } \\
\text { dazole 0.15\% }\end{array}$ & $0.574 \pm 0.03$ & $0.510-0.593$ \\
\hline $\begin{array}{l}\text { Chitosan hydrogel-based metroni- } \\
\text { dazol 0.12\% }\end{array}$ & $0.587 \pm 0.03$ & $0.510-0.593$ \\
\hline 3\% Chitosan Hydrogel & $0.575 \pm 0.02$ & $0.513-0.591$ \\
\hline
\end{tabular}


Table 3. Viability percentage of chitosan hidrogel based metronidazole on 3T3 fibroblast cells

\begin{tabular}{|l|c|c|}
\hline & $\begin{array}{c}\text { \% Viability } \\
\text { Mean } \pm \text { SD }\end{array}$ & Min - Max \\
\hline 3\% Chitosan hydrogel & $98.8 \pm 0.44$ & $98-99$ \\
\hline $\begin{array}{l}\text { Chitosan hydrogel-based metro- } \\
\text { nidazole 0.25\% }\end{array}$ & $90.4 \pm 2.40$ & $90-92$ \\
\hline $\begin{array}{l}\text { Chitosan hydrogel-based metro- } \\
\text { nidazole 0.15\% }\end{array}$ & $92.6 \pm 2.07$ & $92-94$ \\
\hline $\begin{array}{l}\text { Chitosan hydrogel-based metro- } \\
\text { nidazole 0.12\% }\end{array}$ & $96 \pm 1.58$ & $95-97$ \\
\hline
\end{tabular}

Table 4. Normality test results

\begin{tabular}{|c|c|}
\hline \% Viability & Significance \\
\hline Chitosan hydrogel-based metronidazole $0.12 \%$ & 0.801 \\
\hline Chitosan hydrogel-based metronidazole $0.15 \%$ & 0.141 \\
\hline Chitosan hydrogel-based metronidazole $0.25 \%$ & 0.174 \\
\hline 3\% Chitosan hydrogel & 0.697 \\
\hline
\end{tabular}

Saphiro-Wilk Normality test $(\mathrm{p}>0.05)$

Table 5. Comparison of chitosan hydrogel based metronidazole cytotoxic effect on 3T3 fibroblast cell

\begin{tabular}{|l|c|c|c|c|c|}
\hline \multicolumn{1}{|c|}{ Variable } & $\begin{array}{c}\text { Viability } \\
\text { Mean }\end{array}$ & $\begin{array}{c}\text { Chitosan hy- } \\
\text { drogel-based } \\
\text { metronidazole } \\
\mathbf{0 . 1 2 \%}\end{array}$ & $\begin{array}{c}\text { Chitosan hy- } \\
\text { drogel-based } \\
\text { metronida- } \\
\text { zole0.15\% }\end{array}$ & $\begin{array}{c}\text { Chitosan hy- } \\
\text { drogel- based } \\
\text { metronida- } \\
\text { zole 0.25\% }\end{array}$ & $\begin{array}{c}\mathbf{3 \%} \\
\text { Chitosa } \\
\text { n hy- } \\
\text { drogel }\end{array}$ \\
\hline $\begin{array}{l}\text { Chitosan hydrogel- } \\
\text { based metronidazol } \\
0.12 \%\end{array}$ & 96.0 & - & $0.007^{*}$ & $0.000^{*}$ & $0.000^{*}$ \\
\hline $\begin{array}{l}\text { Chitosan hydrogel- } \\
\text { based metronidazol } \\
0.15 \%\end{array}$ & 92.6 & $0.007^{*}$ & - & $0.000^{*}$ & $0.000^{*}$ \\
\hline $\begin{array}{l}\text { Chitosan hydrogel- } \\
\text { based metronidazol } \\
0.25 \%\end{array}$ & 90.4 & $0.000^{*}$ & $0.000^{*}$ & - & $0.000^{*}$ \\
\hline $\begin{array}{l}3 \% \text { Chitosan hydro- } \\
\text { gel }\end{array}$ & 98.8 & $0.000^{*}$ & $0.000^{*}$ & $0.000^{*}$ & - \\
\hline
\end{tabular}

ANOVA test*Significant $(\mathrm{p}<0.05)$

The ANOVA test result on table 5 shows that all concentrations of the chitosan hydrogel-based metronidazole shows significantly difference in 3T3 fibroblast cells viability.

\section{Discussion}

This study showed that chitosan hydrogel based metronidazole gel $(0.12 \%, 0.15 \%$ and $0.25 \%$ ) has an non-toxic effect on $3 \mathrm{~T} 3$ fibroblast cells, as the average cell viability percentage is above $90 \%$. Pursuant to ISO 10993-5 standards, percentages of cell viability above $80 \%$ are considered non-cytotoxic; between $80 \%$ to $60 \%$ are 
considered weak; viability percentages between $60 \%$ to $40 \%$ are considered moderate and viability percentages below $40 \%$ are considered strong [16].

The highest viability percentage for 3T3 fibroblast cells (98.8\%) was found in the $3 \%$ chitosan hydrogel group, followed by the $0.12 \%$ metronidazole gel (96\%) and $0.15 \%$ metronidazole gel groups $(92.6 \%)$. The lowest viability percentage (90.4\%) was seen in the $0.25 \%$ metronidazole gel group. The viability percentage of 3T3 fibroblast cells with chitosan hydrogel-based metronidazole $(0.12 \%, 0.15 \%$, and $0.25 \%$ ) and $3 \%$ chitosan hydrogel showed a significantly different result ( $\mathrm{p}>$ 0.05 ). The highest percentage of $3 \mathrm{~T} 3$ fibroblast cell viability was found in the $3 \%$ chitosan hydrogel application, with a mean of $98.8 \%$, The lowest percentage of cell viability was found in the $0.25 \%$ chitosan hydrogel-based metronidazol, with a mean of $90.4 \%$.

This study used 3\% chitosan dissolved in $2 \%$ lactic acid. Based on Popa et al study states that higher concentration of chitosan will reduce the drug-releasing abilities. Research conducted by Yellanki et al. where $0.25 \%$ metronidazole dissolved in $2 \%$ lactic acid and 3\% chitosan result showed a higher concentration of the drug, bioadhesive better and more controlled drug release $[1,13]$.

Chitosan is a hydrophilic polysaccharide derived from the exoskeleton of crustaceans, such as shrimp, crab and other sea crustaceans [17]. This study used chitosan from crabs. Chitosan is a non-toxic, biocompatible and inexpensive substance that is effective in releasing in the drug [18].

Grobler et al. says that $3 \mathrm{~T} 3$ fibroblast cells have been widely used for many years as standard in cytotoxicity tests because they have similarities with human fibroblasts of human tooth pulp. Fibroblasts are the main cells in connective tissue, which is located in the lamina propria of the oral mucosa and the gingiva. The observation of viability in cultured fibroblast cell can be used as an indicator to determine the effect of concentration and exposure to a substance, including the cytotoxicity effects [18].

The aboved discussion show that chitosan hydrogel-based metronidazole $(0.12 \%, 0.15 \%$ and $0.25 \%)$ did not show cytotoxic properties in $3 \mathrm{~T} 3$ fibroblast cells. This is a basis for further research, because chitosan hydrogel-based metronidazole may later be used clinically as a supportive periodontal treatment.

\section{Conclusions}

Chitosan hydrogel-based metronidazole $0.12 \%, 0.15 \%, 0.25 \%$ and $3 \%$ chitosan hidrogel shows a higher viability percentage and is not cytotoxic in 3T3 fibroblast cell. $3 \%$ chitosan hydrogel shows good biocompatibility characteristics on $3 \mathrm{~T} 3$ fibroblast cell.

\section{References}

1. Yellanki SK, Singh J, Manvi FV. Formulation, characterization and evaluation of metronidazole gel for local treatment of periodontitis. Int $\mathrm{J}$ Pharma Bio Sci. 2010;1(2):1-9.

2. Rajagopalan A, Thomas JT. Effectiveness of Metronidazole as Local Drug Delivery in Periodontal Diseases-A Review. IOSR J Dent Med Sci. 2014;13(8):25-8. 
3. Kesic L, Milasin J, Igic M, Obradovic R. Microbial etiology of periodontal disease-mini review. Med Biol. 2008;15(1):1-6.

4. Griffiths GS, Smart GJ, Bulman JS, Weiss G, Shrowder J, Newman HN. Comparison of clinical outcomes following treatment of chronic adult periodontitis with subgingival scaling or subgingival scaling plus metronidazole gel. $\mathrm{J}$ Clin Periodont. 2000;27(12):910-7.

5. Kotsilkov K, Popova C, Dosseva V. Effectivness of Target Antimicrobial Therapy of Severe Chronic Periodontitis Part i: Reduction of Gingival Inflamation and Active Periodontal Disease Sites. Jimab. 2010;16(4):18-20.

6. Krämer M, Sahrmann P, Sener B, Thurnheer T, Attin T, Schmidlin PR. Iodine release and antibacterial effects of a wound paste combined with PVP-iodine powder and/or solution in vitro. Int J Dent Res. 2013;1(1):1-7.

7. Pejčić A, Kesić L, Obradović R, Mirković D. Antibiotics in the Management of Periodontal Disease. Acta facultatis medicae Naissensis. 2010 Jun 1;27(2).

8. Dumitrescu AL, Ohara M. The Topical Use of Antibiotics in Periodontal Pockets. In: Antibiotics and Antiseptics in Periodontal Therapy. Verlag Berlin, Heidelberg. Spring. 2011:171-5.

9. Kaplish V, Walia MK, Kumar HS. Local drug delivery systems in the treatment of periodontitis: A review. Pharmacophore. 2013;4(2):39-49.

10. Mombelli A. Antibiotics in Periodontal Therapy. In: Lindhe J, Lang NP. Clinical Periodontology and Implan Dentistry, 5th ed, Blackwell Musgard. 2008:884-5.

11. Sato S, Fonseca MJ, Ciampo JO, Jabor JR, Pedrazzi V. Metronidazole-containing gel for the treatment of periodontitis: an in vivo evaluation. Brazilian Oral Res. 2008;22(2):145-50.

12. Ray M, Pal K, Anis A, Banthia AK. Development and characterization of chitosan-based polymeric hydrogel membranes. Designed Monomers and Polymers. 2010 ;13(3):193206.

13. Popa LĂ, Ghica MV, Dinu-Pirvu CR. Periodontal chitosan-gels designed for improved local intra-pocket drug delivery. Farmacia. 2013;61(2):240-50.

14. Bhattarai N, Gunn J, Zhang M. Chitosan-based hydrogels for controlled, localized drug delivery. Advanced drug delivery reviews. $2010 ; 62(1): 83-99$.

15. Adha N, Ervina I, Agusnar H. The effectiveness of metronidazole gel based chitosan inhibits the growth of bacteria Aggregatibacter actinomycetemcomitans, Porphyromonas gingivalis, Fusobacterium nucleatum (In vitro).

16. López-García J, Lehocký M, Humpolíček P, Sáha P. HaCaT keratinocytes response on antimicrobial atelocollagen substrates: extent of cytotoxicity, cell viability and proliferation. Journal of functional biomaterials. 2014 May 8;5(2):43-57.

17. Gavhane YN, Gurav AS, Yadav AV. Chitosan and its applications: a review of literature. Int J Biomed Pharm Sci. 2013; 4:312-31.

18. Grobler SR. Cytotoxic Effect of Chitosan-H, Resveratrol, $\beta$-Carotene and Propolisand their Chitosan Hydro-gels On Balb/C Mouse 3T3 Fibroblast Cells. Int J Dentistry Oral Sci. 2014 Dec 11;1(2):10-4. 